\title{
THE STRATIGRAPHY OF THE FISKENÆSSET ANORTHOSITE COMPLEX
}

\section{Brian F. Windley}

In the Fiskenæsset region metamorphosed anorthosites occur as conformable layers up to about $2 \mathrm{~km}$ thick in high-grade gneisses. It has been found that within the layers there is a well preserved primary stratigraphy which can be followed persistently along the strike on Qeqertarssuatsiaq, west and east Taseq and the south side of Fiskenæsfjorden, a distance of at least $60 \mathrm{~km}$. Because of tectonic thinning of layers, especially in fold limbs, and to a lesser extent because of primary lateral variations, any one traverse across the complex may display an incomplete stratigraphic section. By taking these variations into consideration the following maximum, composite stratigraphy has been found:

\section{Major Units}

Minor Units

Top

10 Pyroxene amphibolite

9 Ultramafic group

Sapphirine rocks

8 Garnet anorthosite

7 Hornblende chromitite

6 Anorthosite

5 Ophitic gabbro

4 Mafic gabbro

Mafic gabbro (W. Taseq)

Mafic gabbro (E. Taseq)

Mafic gabbro (W. Taseq)

3 Lower layered group

2 Ultramafic group

1 Pyroxene amphibolite

\section{Bottom}

Chromite-layered bronzitite

The rock types have been divided into different classes depending on their percentage of mafic minerals as follows:

$\begin{array}{lr}\text { Anorthosite } & <10 \% \\ \text { Gabbroic anorthosite } & 10-20 \\ \text { Anorthositic gabbro } & 20-30 \\ \text { Gabbro } & 30-60 \\ \text { Mafic gabbro } & 60-90 \\ \text { Ultramafic rocks } & >90\end{array}$

The ophitic gabbros have previously been called "gabbro anorthosite", but this was a field term applied without a strict mineralogical definition. The mafic gabbros occupy different positions in the stratigraphy in different areas but are normally 


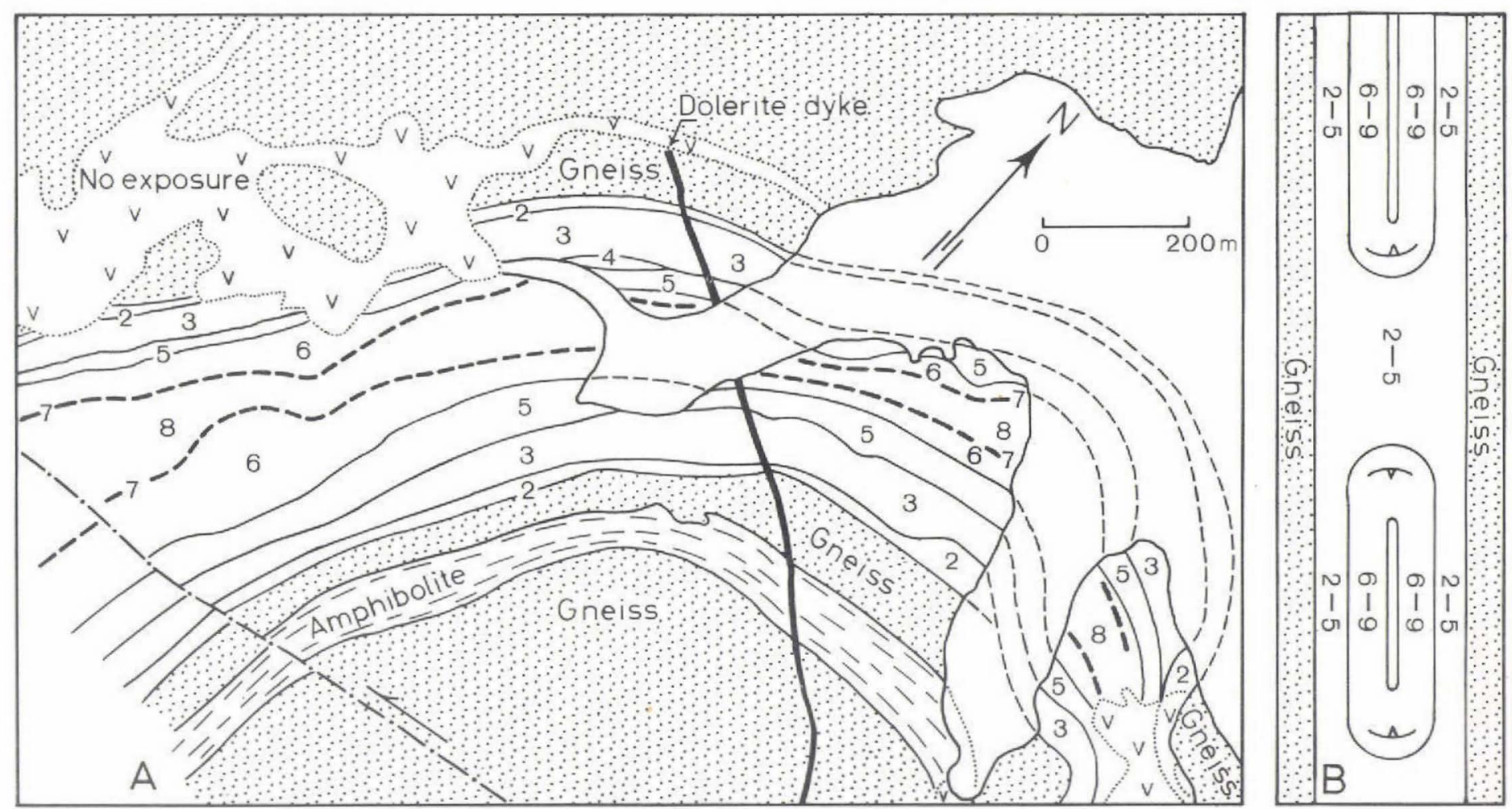

Fig. 4. Detailed map of the stratigraphy in layered anorthosite on the north-east coast of Qeqertarssuatsiaq. 
associated with the ophitic gabbros in the lower part of the column. The "lower layered group", has a complex stratigraphy of intercalated streaks, laminae and layers of gabbro anorthosite, anorthositic gabbro, layered ophitic gabbro and minor anorthosite. Garnets are characteristic of zone 8, often concentrated in thin layers or occurring sporadically throughout the anorthosite. The garnet-bearing zone is a definite marker horizon which can be used for locating the chromitites of zone 7 which are antipathetic with all other zones of the complex. By locating oneself in the correct position in the stratigraphy it is possible to find the chromitite layers easily even when they are only $5-10 \mathrm{~cm}$ thick; applying the stratigraphy it was found that there are several times more chromite in the complex than was reported by Ghisler \& Windley (1967). In searching for metals such as platinum the stratigraphy provides the key to locating specific horizons at any position in the complex. The sapphirine-bearing rocks are also stratigraphically controlled along the contact of the upper amphibolite and the ultramafics of zone 9.

The complex has a double or repeated stratigraphy arranged symmetrically. One passes from zone 1 at the outside through zones 2 to 9 to zone 10 at the centre and then symmetrically again through zones 10 to 1 (see fig. $4 \mathrm{~A}$ ). The complex has an internal structure similar to that of the Great Dyke (Worst, 1960) in that it has internal closures (see fig. 4 B). The higher inner zones 6-10 close isoclinally and the lower mafic zones 1-5 continue along the strike.

Bowden (1970) made a geochemical traverse across the complex in central Qeqertarssuatsiaq in the form of $21 \mathrm{X}$-ray fluorescence analyses of rocks arranged in stratigraphic order. He found that there was an appreciable Fe enrichment from the bottom (outermost) layers to the top (centre) and marked differentiation trends symmetrically arranged in reverse order on either side of the complex. This way-up evidence indicates that the lower part of the complex is predominantly mafic and the upper anorthositic, and that the orthopyroxene chromitites (chromite-layered bronzitites) occur in the lower mafic part and the hornblende chromitites in the upper anorthosites. Although it is inconclusive, some field and chemical evidence suggests that the pyroxene amphibolites of zones 1 and 10 are metavolcanics unrelated to the complex and this influences the interpretation of the genesis of the prominent sulphides that occur in them.

The original basin shape of the complex was flattened into an isoclinal syncline and then refolded and metamorphosed twice.

It is suggested that the Fiskenæsset complex is the chromite-layered, deep level, root zone of a vast lopolith which probably accounts for many of the similar anorthosites and ophitic gabbros that are common throughout the Archaean of Greenland.

\section{References}

Bowden, A. 1970: Unpublished M.Sc. thesis. University of Leeds, England.

Ghisler, M. \& Windley, B. F. 1967: The chromite deposits of the Fiskenæsset region, West Greenland.

Rapp. Grønlands geol. Unders. 12, $38 \mathrm{pp}$.

Worst, B. G. 1960: The Great Dyke of Southern Rhodesia. Bull. geol. Surv. Sth. Rhod. 47, 234 pp. 